Uploaded : December 2020

Accepted : January 2021

Published : June 2021

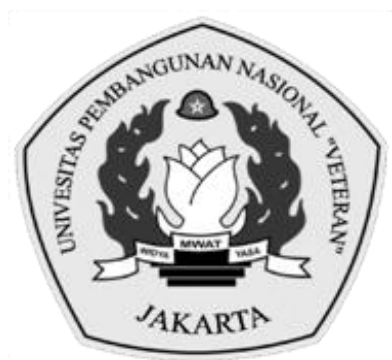

\title{
AUDIT OPINION AND AUDIT CHARACTERISTIC: STUDY OF VOLUNTARY AUDITOR SWITCHING
}

\author{
Ni Putu Shinta Dewi ${ }^{1}$, Ni Luh Putu Tara Verjinia Febriyanti ${ }^{2}$, Ni Wayan Rustiarini ${ }^{3 *}$ \\ ${ }^{1}$ shintadewi@unmas.ac.id, ${ }^{2}$ taraverjinia17@gmail.com, ${ }^{3}$ rusti_arini@unmas.ac.id \\ 1,2,3Universitas Mahasaraswati Denpasar, Indonesia \\ *corresponding author
}

\begin{abstract}
The switching of auditors is the change of auditors (or public accounting firms) in the company. Voluntary auditor changes are made according to the client's request. This study identifies the factors that influence voluntary auditor turnover. This research population is all manufacturing companies listed on the Indonesia Stock Exchange in 2017-2019. There are 294 samples selected using a purposive sampling method. Hypothesis testing uses a logistic regression analysis. The results showed that audit fees and auditor tenure had a positive effect on auditor turnover. However, three other factors, namely audit opinion, going concern opinion, and audit reporting lag, do not affect auditor turnover.
\end{abstract}

Keywords: Audit Fee; Audit Opinion; Going Concern Opinion; Audit Reporting Lag; Audit Tenure.

\begin{abstract}
Abstrak
Pergantian auditor adalah terjadinya pergantian auditor (atau kantor akuntan publik) pada perusahaan. Pergantian auditor sukarela dilakukan sesuai dengan permintaan klien. Studi ini mengidentifikasi kembali faktor-faktor yang mempengaruhi pergantian auditor sukarela. Populasi penelitian ini adalah seluruh perusahaan manufaktur yang terdaftar di Bursa Efek Indonesia tahun 2017-2019. Terdapat 294 sampel yang dipilih menggunakan metode purposive sampling. Pengujian hipotesis menggunakan analisis regresi logistik. Hasil penelitian menunjukkan bahwa biaya audit dan masa kerja auditor berpengaruh positif terhadap pergantian auditor. Meskipun demikian, tiga faktor lainnya yaitu opini audit, opini going concern, dan audit reporting lag tidak berpengaruh terhadap pergantian auditor.
\end{abstract}

Kata Kunci: Biaya Audit; Opini Audit; Opini Going Concern; Audit Reporting Lag; Masa Kerja Audit.

\section{INTRODUCTION}

The publication of financial reports is an obligation for companies that have gone public. The more companies that go public, the more public accounting services are needed. This condition causes public accounting firms to compete to get clients by providing high-quality audit services possible. On the other hand, the companies choose whether to keep the old auditor or change auditors. There are 
two types of auditor switching: mandatory and voluntary (Adli and Suryani, 2019). This study explicitly discusses voluntary auditor switching.

In Indonesia, the government has formulated a policy regarding auditor rotation. The latest provisions regarding the change of auditors are contained in Government Regulation No. 20 of 2015 concerning "Public Accountant Practice." In this policy, the government emphasizes tightening public accountants' supervision who audit corporate financial statements, particularly the financial services sector. The provision of audit services on historical financial information for an entity by a public accountant is limited to five consecutive financial years. Nonetheless, there is no limitation on the audit duration for public accounting firms. One of the auditor switching cases that caught the public's attention in 2018 occurred at PT. Tiga Pilar Sejahtera Food. In this case, auditors' switching was made due to irregularities in the audit report and frequent publication of the audited financial statements. These irregularities were found in the ledger records, transaction details, and other financial data. Ironically, these records are different from the records used by independent auditors in auditing (CNBCIndonesia, 2019). Finally, this incident forced the company to make a voluntary switching of auditors.

Although many academics have studied the factors that influence auditor switching, these results still show inconsistencies. For example, in the audit opinion variable, both unqualified opinion and going concern opinion. Audit opinion, which is the information used by external users of financial statements for investment decisions. Empirical evidence shows that audit opinions in the previous year tend to cause companies to switch auditors (Hermawan and Fitriany, 2013; Stanisic et al., 2014; Heliodoro, Carreira and Lopes, 2015; Faradila et al., 2016; Gharibi and Geraeely, 2016; Darmayanti, 2017). Other evidence finds that audit opinion does not affect auditors switching (Chadegani, Arezoo Aghaei Mohamed, Muhammaddun and Jari, 2011; Khasharmeh, 2015; Stephanie and Prabowo, 2017). Going concern opinion also influences the auditors switching. On the one hand, going concern opinion positively affects auditor switching (Khasharmeh, 2015; Pradhana and Suputra, 2015; Wijaya and Rasmini, 2015). On the other hand, going concern opinion has a negative effect on auditor switching (Yudha and Saputra, 2017).

Audit characteristic factors can be reviewed from the audit fee, audit reporting lag, and audit tenure. The audit fee is a crucial factor that often motivates companies to change auditors is the audit fee. Several studies have shown that audit fee has a positive effect on auditor switching (Calderon and Ofobike, 2008; Astuti and Ramantha, 2014; Khasharmeh, 2015; Pradhana and Suputra, 2015; Sharma, Tanyi and Litt, 2016), while other researchers found those audit fees have a negative effect on auditor switching (Adli and Suryani, 2019). Other researchers have found no relationship between these two variables (Chadegani, Arezoo Aghaei Mohamed, Muhammaddun and Jari, 2011; Khasharmeh, 2015; Stephanie and Prabowo, 2017; Udayani and Badera, 2017). The second audit characteristic factor is the delay in publishing financial reports. The longer the time to publish financial reports, the more likely the information is is leaked to investors. Therefore, if there is an audit reporting lag, the company will switch auditors in the coming year (Ruroh and Rahmawati, 2016; Sharma, Tanyi and Litt, 2016; Arisudhana, 2017). In contrast, other studies have found that audit reporting lag 
has a negative effect on auditor switching (Blankley, Hurtt and MacGregor, 2014; Whitworth and Lambert, 2014; Chan, Luo, and Mo, 2016; Dong, Robinson and Xu, 2018; Wati, 2020). Another factor is public accounting firm tenure. Previous empirical studies found that audit tenure has a positive effect (Astrini and Muid, 2013), but other research disclose a negative effect on auditor switching (Gul, Fung and Jaggi, 2009; Dhaliwal et al., 2013).

This research is motivated by two reasons. First, the issue of "auditor switching" has implications for financial reporting credibility and monitoring costs (Huson, Parrino, and Starks, 2001). Although academics and practitioners have extensively studied auditor switching in Indonesia, several studies are still inconsistent. This condition causes academics not to get robust results related to the factors that influence auditor switching. Thus, this study re-identifies the factors that influence auditor switching to reinforce the results of previous studies. Second, the company has not conveyed so far in writing the reasons for auditor change in the annual report. Also, the reasons for changing auditors are often not conveyed to stakeholders. Companies are trying to hide the facts behind the auditor change process because it will reveal the company's real problems (Nazri, Smith, and Ismail, 2012). Based on this phenomenon, it is necessary and exciting to explore the factors that lead to auditor switching, mainly voluntary switching.

Therefore, this research aims to reexamine the role of audit and go concern opinions, audit fees, audit reporting lags, and audit tenure on voluntary auditor switching. The research was conducted on 294 manufacturing sector companies listed on the Indonesia Stock Exchange in 2017-2019. The results showed that audit fees and audit tenure had a positive effect on auditor switching. However, audit opinion, going concern opinion, and audit reporting lag do not affect auditor switching.

This research has theoretical and practical benefits. Theoretically, it confirms the role of Agency Theory in the phenomenon of voluntary auditor switching. Also, this study provides additional empirical studies related to the factors that can determine auditor switching. This study provides additional references to management regarding the company's policies in auditor switching in practical terms. This study can also provide investors and potential investors information about potential problems hidden by management behind the auditor change process.

\section{LITERATURE REVIEW}

\section{Agency Theory}

Agency theory illustrates the relationship between principal and agency agreed upon and realized in a work contract (Jensen and Meckling, 1976). This relationship creates a conflict of interest as one of the triggers for auditor change. Management as the party who understands the company's condition often has different interests and goals with shareholders (Lesmana and Kurnia, 2016). Therefore, an independent auditor must mediate agency problems between the company owners and the company managers. 


\section{Audit Opinion and Auditor Switching}

The auditor provides an opinion statement regarding assessing financial statements' accuracy, and it is called audit opinion. Generally, corporate clients like an unqualified opinion, which shows fairness in the financial statements, and there is no deviation from the prevailing accounting standards. Therefore, in a voluntary auditor switching, the audit opinion that is not by the client's expectations often motivates management to change auditors. It cannot be denied that audit opinions that do not match management's expectations result in a decrease in share prices and financial reports' credibility (Skinner and Srinivasan, 2012). Referring to previous research (Hermawan and Fitriany, 2013; Stanisic et al., 2014; Heliodoro, Carreira and Lopes, 2015; Faradila et al., 2016; Gharibi and Geraeely, 2016; Darmayanti, 2017), audit opinion has a positive effect on auditor switching. Thus, a hypothesis is formulated:

\section{H1: Audit opinion has a positive effect on auditor switching.}

\section{Going Concern Opinions and Auditor Switching}

One of the auditor's opinions to ensure the company's survival is a going concern opinion. Auditors can convince users of financial statements that the company's viability has been disclosed in the audited report when conducting audits. Companies that get going concerning opinion often get negative responses from stakeholders (Svanberg and Ohman, 2014). Management that is not satisfied with the performance of the auditors tends to change auditors. This action is a form of punishment for giving opinions that are not following company expectations. The change of auditors is carried out so that the company gets auditors who are easier to manage. Based on previous research (Khasharmeh, 2015; Pradhana and Suputra, 2015; Wijaya and Rasmini, 2015), it was found that going concern opinion has a positive effect on auditor switching. Thus, a hypothesis is formulated:

H2: Going concern opinion has a positive effect on auditor switching.

\section{Audit Fee and Auditor Switching}

Audit fees are fees that must be paid for the audit services performed. Determination of the fee amount will be adjusted to the standard of fairness, level of difficulty (complexity), and time to complete the assigned audit work (Calderon and Ofobike, 2008; Khasharmeh, 2015). If the auditor sets the fee value too high, the company will look for an alternative auditor to provide a lower fee value. Thus, the audit fee will not add to the company's burden (Wijaya and Rasmini, 2015). However, bidding fees that are too high also can lead to non-compliance with the code of ethics for public accountants. Therefore, the fee must meet a fairness figure so that the auditors can perform audit procedures adequately. Previous research believes that audit fees positively affect auditor switching (Calderon and Ofobike, 2008; Astuti and Ramantha, 2014; Khasharmeh, 2015; Pradhana and Suputra, 2015; Sharma, Tanyi and Litt, 2016). Thus, a hypothesis is formulated:

H3: Audit fees have a positive effect on auditor switching. 


\section{Audit Reporting Lag and Auditor Switching}

ARL is the length of time to complete the audit process of a company financial report. The audit period greatly determines the company's timeliness in submitting financial reports to regulators. The more complex or complicated an audit process is, the longer it takes the auditor to complete fieldwork. Of course, it causes delays in the publication of financial reports. Also, the greater the chance of information leakage to investors or insider traders. Based on the previous empirical research (Ruroh and Rahmawati, 2016; Sharma, Tanyi and Litt, 2016; Arisudhana, 2017) found that audit reporting lag has a positive effect on auditor switching. Thus, a hypothesis is formulated:

\section{H4: Audit reporting lag has a positive effect on auditor switching.}

\section{Audit Tenure and Auditor Switching}

Audit tenure is an audit engagement period between a public accounting firm and a company (client). Audit tenure also defines as the time or period of the auditor and client relationship. Some researchers believe that long audit tenure can reduce auditors' work (Dhaliwal et al., 2013). A long audit tenure also creates a strong personal bond between the auditor (public accounting firm) and the client. It indirectly reduces the independence of an auditor. Therefore, companies tend to change auditors to obtain quality audit findings (Astrini and Muid, 2013). Thus, a hypothesis is formulated:

H5: Audit tenure has a positive effect on auditor switching.

\section{RESEARCH METHODOLOGY}

\section{Population and Sample}

This study is an archival method that uses company financial report data published on the Indonesian Stock Exchange. This study's population are all manufacturing companies on the Indonesia Stock Exchange for 2017 - 2019. Based on the purposive sampling method, 98 companies meet the specified criteria. Thus, the sample used in this study is 294. This study uses secondary data, such as financial reports that were accessed from the IDX website www.idx.co.id.

\section{Research Variables}

The dependent variable is a voluntary auditor switching. The variable is measured using a dummy, namely companies that make voluntary changes in auditors (public accountants) are given a value of 1 . If not, then they are given a value of 0 . This study uses five independent variables: audit opinion, going concern opinion, audit fee, audit reporting lag, and tenure audits. The audit opinion is measured by a dummy, given code one if the company gets an opinion other than an unqualified opinion. In contrast, code 0 is given if it gets an unqualified opinion. Measurement for the going concern opinion variable is also measured using a dummy, code 1 for manufacturing companies that accept going concern audit opinion, and vice versa. The audit fee variable is proxied by the natural logarithm of the value of professional fees listed in its financial statements. The audit reporting lag variable is calculated by calculating the number of days from the 
company's books' closing date to the audit report's date. Another independent variable, namely audit tenure, is calculated by adding the total length of the public accounting firm's audit tenure before moving. The first year of engagement starts with the number 1 and is added by one for the following years. Hypothesis testing uses a logistic regression analysis.

\section{RESULT AND DISCUSSIONS}

\section{Result}

The test results using logistic regression show the goodness of fit test, overall model fit test, coefficient of determination, classification test results, multicollinearity test results, and logistic regression test results. The Goodness of Fit test results conducted using Hosmer and Lemeshow's Good of Fit test are shown in Table 1.

Table 1. The goodness of Fit Test

\begin{tabular}{cccc}
\hline Step & Chi-square & df & Sig. \\
\hline 1 & 13.576 & 8 & .094 \\
\hline
\end{tabular}

Source: Processed data (2020)

Hosmer and Lemeshow's Good of Fit Test's statistical value in Table 1 is 13.576 , with a significant probability of 0.094 , which is above 0.05 . From these results, the model can predict the value of the observation. Next, a test is conducted to assess the overall model shown in Table 2.

Table 2. Overall Model Fit Test

\begin{tabular}{cc}
\hline -2 Log Likelihood Block Number = 0 & -2 Log Likelihood Block Number = 1 \\
\hline 407,448 & 379,687 \\
\hline
\end{tabular}

Source: Processed data (2020)

Table 2 shows that the initial number -2 log Likelihood Block Number $=0$ is 407,448 , and after entering the five independent variables, the -2 log-likelihood Block Number $=1$ value has decreased to 379,687 . Thus, the regression model is fit with the data. The next test is the coefficient of determination test shown in Table 3.

Table 3. Determination Coefficient Test Results

\begin{tabular}{cccc}
\hline Step & $\mathbf{- 2 ~ L o g ~ L i k e l i h o o d}$ & Cox \& Snell R Square & Nagelkerke R Square \\
\hline 1 & $379.687^{a}$ & -.090 & -.120 \\
\hline
\end{tabular}

Source: Processed data (2020)

The test results in Table 3 disclose that the Nagelkerke R square value of 0.120 indicates that the dependent variable's variability, which can be explained by the independent variable, is $12 \%$. In comparison, other variables explain the remaining $88 \%$. 
Table 4. Classification Test Results

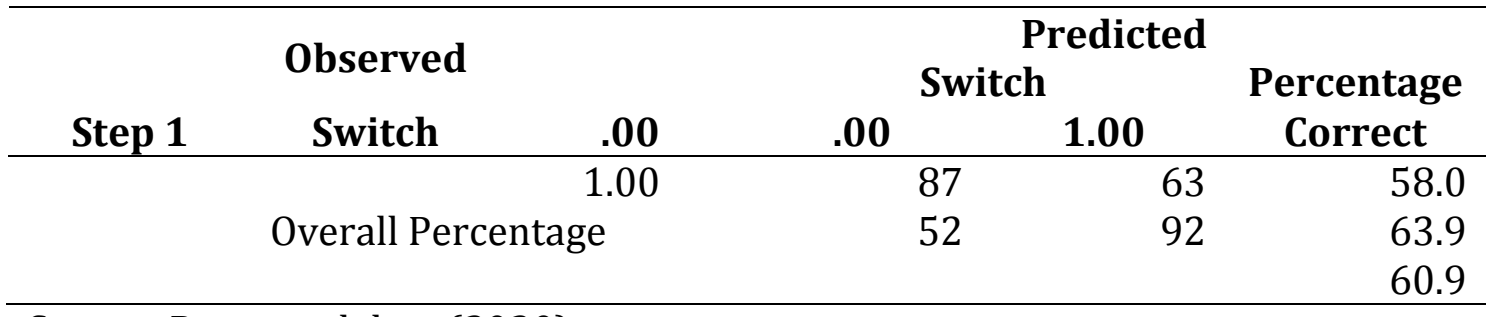

Source: Processed data (2020)

The classification test results in Table 4 disclose the regression model's predictive power to predict the possibility of switching auditors by the company, namely $63.90 \%$ of companies that will switch auditors. The regression model's predictive power to predict its probability will not be switching auditors is $58.00 \%$. With this regression model, 63 companies did not change auditors from 150 companies that did not change auditors. Thus, the overall percentage of prediction accuracy is $60.9 \%$. The next test is the multicollinearity test shown in Table 5.

Table 5. Multicollinearity Test Results

\begin{tabular}{llrrrrrr}
\hline & & Constant & \multicolumn{1}{c}{$\begin{array}{c}\text { Audit } \\
\text { fee }\end{array}$} & $\begin{array}{c}\text { Audit } \\
\text { opinion }\end{array}$ & $\begin{array}{c}\text { Going } \\
\text { concern } \\
\text { opinion }\end{array}$ & $\begin{array}{c}\text { Audit } \\
\text { reporting } \\
\text { lag }\end{array}$ & $\begin{array}{c}\text { Audit } \\
\text { tenure }\end{array}$ \\
\hline Step & & & & & -0.615 & -0.200 & -0.101 \\
1 & Constant & 1.000 & -0.792 & -0.315 & -0.615 & -0.027 & -0.016 \\
& Audit opinion & -0.315 & 0.050 & 1.000 & 0.133 & -960 \\
& Going concern opinion & -0.615 & 0.085 & 0.133 & 1.000 & 0.041 & 0.960 \\
& Audit fee & -0.792 & 1.000 & 0.050 & 0.085 & 0.181 & -0.108 \\
& Audit reporting lag & -0.200 & 0.181 & -0.027 & 0.041 & 1.000 & -0.097 \\
& Audit tenure & -0.101 & -0.108 & -0.016 & 0.096 & -0.097 & 1.000 \\
\hline
\end{tabular}

Source: Processed data (2020)

The test results in Table 5 show that there is no correlation coefficient value between independent variables whose value is more significant than 0.8 . Thus, there is no indication of multicollinearity between the independent variables.

Table 6. Logistic Regression Test Results

\begin{tabular}{clrrrrrr}
\hline & & B & S.E & \multicolumn{1}{c}{ Wald } & df & Sig. & Exp (B) \\
\hline Step & Audit opinion & 0.000 & 0.004 & 0.001 & 1 & 0.969 & 1.000 \\
1 & Going concern opinion & -0.861 & 0.897 & 0.921 & 1 & 0.337 & 0.423 \\
& Audit fee & 0.137 & 0.058 & 5.552 & 1 & 0.018 & 1.146 \\
& Audit reporting lag & 0.003 & 0.003 & 1.219 & 1 & 0.270 & 1.003 \\
& Audit tenure & 0.331 & 0.085 & 15.345 & 1 & 0.000 & 1.392 \\
& Constant & -1.352 & 1.731 & 0.610 & 1 & 0.435 & 0.259 \\
\hline
\end{tabular}

Source: Processed data (2020)

Table 6 shows the test results with logistic regression at a significance of $5 \%$. The results showed that audit fees and audit tenure had a positive effect on auditor switching. Audit opinion, going concern opinion, and audit reporting lag do not affect auditor switching. 


\section{Discussion}

The first hypothesis states that audit opinion has a positive effect on auditor switching. The results indicate that the audit opinion variable does not affect auditor switching. Thus, H1 was rejected. Theoretically, the company makes a voluntary change of auditors if the public accounting firm issues an audit opinion that does not match the company management's expectations (Stanisic et al., 2014; Heliodoro, Carreira and Lopes, 2015). Companies that get an opinion other than an unqualified opinion are considered to have a bad reputation. Company management dissatisfaction with the published audit opinion can lead to tension in management and auditors' relationship. Therefore, the client company decides to switch auditors. However, empirical evidence indicates the opposite condition. Although the company did not get an unqualified opinion, the company did not change auditors. This condition is probably because most of the samples in this study received an unqualified opinion not to affect auditor switching. Thus, this study's results support the empirical research (Chadegani, Arezoo Aghaei Mohamed, Muhammaddun and Jari, 2011; Khasharmeh, 2015; Stephanie and Prabowo, 2017) are also unable to prove the effect of audit opinion on auditor switching empirically. However, this empirical study does not support the previous research that found that audit opinion has a positive effect on auditor switching (Hermawan and Fitriany, 2013; Stanisic et al., 2014; Heliodoro, Carreira and Lopes, 2015; Faradila et al., 2016; Gharibi and Geraeely, 2016; Darmayanti, 2017).

The second hypothesis states that going concern opinion has a positive effect on auditor switching. The test results show that going concern opinion does not affect auditor switching. Thus, $\mathrm{H} 2$ was rejected. In general, a going concern opinion is one that the auditor avoids. Companies with a going concern opinion will usually get a negative response from investors. Therefore, companies tend to make voluntary auditor changes. However, the evidence contradicts the formulated hypothesis. This condition occurs because company management considers that a going concern opinion is not wrong (Meryani and Mimba, 2012). The company will improve its performance through a going concern opinion and see changes in the following year. The auditors also provide recommendations for improvements to the company. Although the company changes auditors, they will still accept the opinion again if they do not use the company auditors' recommendations. Thus, this study's results do not support the previous research that found going concern opinion positively affects auditor switching (Khasharmeh, 2015; Pradhana and Suputra, 2015; Wijaya and Rasmini, 2015).

The third hypothesis states that audit fees have a positive effect on auditor switching. This test indicates that the audit fee variable positively affects auditor switching, or H3 is accepted. The financial report audit is one of the principal's efforts to oversee the company's financial management. An independent auditor is a third party who has the authority to access financial statements. Audit fees are monitoring costs incurred to finance the audit process carried out by independent auditors (Kholipah and Suryandari, 2019). The amount of the audit fee is determined by various factors, such as the task complexity, the time required, and conflicts of interest. However, the audit fee size is often a problem for management. If the audit fees offered by the public accounting firm are too high, the company will look for auditors who provide lower audit fees. It was done not 
to increase the company's burden (Wijaya and Rasmini, 2015). However, this study's results support previous studies (Calderon and Ofobike, 2008; Astuti and Ramantha, 2014; Khasharmeh, 2015; Pradhana and Suputra, 2015; Sharma, Tanyi and Litt, 2016). This result contradicts previous empirical evidence that failed to prove the relationship between audit fees and auditor switching (Chadegani, Arezoo Aghaei Mohamed, Muhammaddun and Jari, 2011; Khasharmeh, 2015; Stephanie and Prabowo, 2017; Udayani and Badera, 2017).

The fourth hypothesis states that the audit reporting lag has a positive effect on auditor switching. However, the empirical test shows that the audit reporting lag variable does not affect auditor switching. Thus, H4 was rejected. This result means that even though the auditors' completion is too long or has passed the predetermined time, this condition does not motivate the company's management to change auditors. This phenomenon because most of the samples in this study are large companies that have high business complexity. The more complex the system in the company, the longer it takes the auditor to complete fieldwork. Thus, the audit reporting lag does not motivate companies to switch auditors. Also, the company has concerns about changing auditors. Investors can assume that the company is experiencing problems. Even though there is a delay in submitting financial reports, its management still maintains the old auditor to maintain its reputation (Rezaee, 2005; Sharma, Tanyi and Litt, 2016). Thus, this study's results do not support previous research (Ruroh and Rahmawati, 2016; Sharma, Tanyi, and Litt, 2016; Arisudhana, 2017) the company will switch auditors in the coming year.

The fifth hypothesis states that audit tenure has a positive effect on auditor switching. The results of this test found that the audit tenure variable had a positive effect on auditor switching. Thus, H5 is accepted. It cannot be denied that a long tenure audit can cause a decrease in the quality of auditors. Besides, the audit tenure length creates a personal bond between auditor and client that can demonstrate auditor's independence (Astrini and Muid, 2013). Therefore, companies tend to change auditors to find new findings to improve the quality of financial reports. The company will want improvements and developments to its financial statements. This study's results support Astrini \& Muid's (2013) results but contrary to other research that negatively affects auditor switching (Gul, Fung and Jaggi, 2009; Dhaliwal et al., 2013).

\section{CONCLUSION}

This study aims to reexamine the effect of the audit opinion, going concern opinion, audit fee, audit reporting lag, and audit tenure on auditor switching in manufacturing companies. Based on the test results, audit fee and audit tenure variables positively affect auditor switching. However, the audit opinion variables, going concern opinion, and audit reporting lag do not affect auditor switching. This study is inseparable from its limitations. First, many companies do not disclose the audit fee amount in the company's financial statements. Future studies may seek audit fee data from other sources, thereby increasing the number of samples. Second, the results of this study show a low Nagelkerke R Square, which is $12 \%$. It 
can be interpreted that there are still many other factors that could explain auditor change but were not examined in this study. Thus, further researchers can add audit ethic factors, such as fraudulent financial statements or auditors' dysfunctional behavior.

\section{REFERENCES}

Adli, S. N. and Suryani, E. (2019) 'Pengaruh leverage, pergantian manajemen, dan audit fee terhadap auditor switching', Jurnal ASET (Akuntansi Riset), 11(2), pp. 288-300.

Arisudhana, D. (2017) 'Pengaruh audit delay, ukuran klien, opini audit tahun sebelumnya, reputasi KAP, dan ROA terhadap pergantian auditor sukarela', Jurnal Akuntansi dan Keuangan, 6(1), pp. 100-120. doi: ISSN: 22527141.

Astrini, N. R. and Muid, D. (2013) 'Analisis faktor-faktor yang mempengaruhi perusahaan melakukan auditor switching secara voluntary', Diponogoro Journal of Accounting, 2(3), pp. 634-644.

Astuti, N. L. P. P. N. and Ramantha, I. W. (2014) 'Pengaruh audit fee, opini going concern, financial distress dan ukuran perusahaan pada pergantian auditor', E-Jurnal Akuntansi Universitas Udayana, 7(3), pp. 663-676.

Blankley, A. I., Hurtt, D. N. and MacGregor, J. E. (2014) 'The relationship between audit report lags and future restatements', Auditing: A Journal of Practice \& Theory, 33(2), pp. 27-57. https://doi.org/10.2308/ajpt-50667

Calderon, T. G., and Ofobike, E. (2008) 'Determinants of client-initiated and auditor-initiated auditor changes', Managerial Auditing Journal, 23(1), pp. 4-25. https://doi.org/10.1108/02686900810838146

Chadegani, Arezoo Aghaei Mohamed, Z., Muhammaddun and Jari, A. (2011) 'The determinant factors of auditor switch among companies listed on Tehran Stock Exchange', International Research Journal of Finance and Economics ISSN, 80, pp. 1450-2887.

Chan, K. H., Luo, V. W. and Mo, P. L. L. (2016) 'Determinants and implications of long audit reporting lag: Evidence from China', Accounting and Business Research, 46(2), pp. 145-166. https://doi.org/10.1080/00014788.2015.1039475

CNBCIndonesia (2019) Siapa Auditor Laporan Keuangan 2017 Tiga Pilar Sejahtera?, CNBC Indonesia. Available at: https://www.cnbcindonesia.com/market/20190327122855-17-

63213/siapa-auditor-laporan-keuangan-2017-tiga-pilar-sejahtera

(Accessed: 8 September 2020).

Darmayanti, N. (2017) 'The effect of the audit opinion, financial distress, client size, management turn and KAP size on auditor switching', Journal of Economics, Business \& Accountancy Ventura, 20(2), pp. 237-248. https://doi.org/10.14414/jebav.v20i2.1125

Dhaliwal, D. S. et al. (2013) Management influence on auditor selection and subsequent auditor independence impairments during the post-SOX period, Available at SSRN 2018702. https://doi.org/10.2139/ssrn.2018702

Dong, B., Robinson, D. and $\mathrm{Xu}$, L. (Emily) (2018) 'Auditor-client geographic 
proximity and audit report timeliness', Advances in Accounting, 40, pp. 11$19 . \quad$ doi: $\quad 10.1016 /$ j.adiac.2017.12.001. https://doi.org/10.1016/j.adiac.2017.12.001

Faradila, Y. et al. (2016) 'Pengaruh opini audit, financial distress, dan pertumbuhan perusahaan klien terhadap auditor switching (studi pada perusahaan manufaktur yang terdaftar di Bursa Efek Indonesia Tahun 2010-2014)', Jurnal Ilmiah Mahasiswa Ekonomi Akuntansi (JIMEKA), 1(1), pp. 81-100.

Gharibi, A. K. and Geraeely, M. S. (2016) 'Investigating the effective factors on changing auditor: Evidences of Iranian firms', Problems and Perspectives in Management, 14(3), pp. 401-406. https://doi.org/10.21511/ppm.14(3si).2016.14

Gul, F. A., Fung, S. Y. K. and Jaggi, B. (2009) 'Earnings quality: Some evidence on the role of auditor tenure and auditors' industry expertise', Journal of Accounting and Economics, 47(3), pp. 265-287. doi: 10.1016/j.jacceco.2009.03.001. https://doi.org/10.1016/i.jacceco.2009.03.001

Heliodoro, P. A., Carreira, F. A. and Lopes, M. M. (2015) 'The change of auditor: The Portuguese case', Spanish Accounting Review, 19(2), pp. 181-186. https://doi.org/10.1016/j.rcsar.2015.05.001

Hermawan, D. and Fitriany, A. (2013) 'Analisis faktor-faktor yang mempengaruhi pergantian KAP upgrade, downgrade dan samegrade pada perusahaan yang terdaftar di BEI', in Simposium Nasional Akuntansi XVI, pp. 148-177.

Huson, M. R., Parrino, R., and Starks, L. T. (2001) 'Internal monitoring mechanisms and CEO turnover: A long-term perspective', The Journal of Finance, 56(6), pp. 2265-2297. https://doi.org/10.1111/0022-1082.00405

Jensen, M. C., and Meckling, W. H. (1976) 'Theory of the firm: Managerial behavior, agency costs and ownership structure', Journal of Financial Economics, 3(4), pp. 305-360. https://doi.org/10.1016/0304-405X(76)90026-X

Khasharmeh, H. A. (2015) 'Determinants of auditor switching in Bahraini's listed companies-an empirical study', European Journal of Accounting, Auditing, and Finance Research, 3(11), pp. 73-99.

Kholipah, S. and Suryandari, D. (2019) 'Factors that influence auditor switching financial companies on the IDX for the period 2015-2017', Jurnal Akuntansi, 9(2), pp. 83-96. https://doi.org/10.33369/j.akuntansi.9.2.83-96

Lesmana, K. and Kurnia, R. (2016) 'Analisis pengaruh pergantian manajemen, opini audit tahun sebelumnya, financial distress, ukuran KAP, dan ukuran perusahaan klien terhadap voluntary auditor switching', Jurnal Ultima Accounting, 8(1), pp. 37-52. https://doi.org/10.31937/akuntansi.v8i1.576

Meryani, L. H. and Mimba, N. P. S. H. (2012) 'Pengaruh financial distress, going concern opinion, dan management changes pada voluntary auditor switching', E-Jurnal Akuntansi, 2(3), pp. 629-648.

Nazri, S. N. F. S. M., Smith, M., and Ismail, Z. (2012) 'Factors influencing auditor change: Evidence from Malaysia', Asian Review of Accounting, 20(3), pp. 222-240. doi: 10.1108/13217341211263274. https://doi.org/10.1108/13217341211263274

Pradhana, M. B. and Suputra, I. D. D. (2015) 'Pengaruh audit fee, going concern, financial distress, ukuran perusahaan, pergantian manajemen pada 
pergantian auditor', E-Jurnal Akuntansi, 11(3), pp. 713-729.

Rezaee, Z. (2005) 'Causes, consequences, and deterrence of financial statement fraud', Critical Perspectives on Accounting, 16(3), pp. 277-298. https://doi.org/10.1016/S1045-2354(03)00072-8

Ruroh, F. M. and Rahmawati, D. (2016) 'Pengaruh pergantian manajemen, kesulitan keuangan, ukuran KAP, dan audit delay terhadap auditor switching', Nominal: Barometer Riset Akuntansi dan Manajemen, 5(2), pp. 68-80. https://doi.org/10.21831/nominal.v5i2.11726

Sharma, D. S., Tanyi, P. N. and Litt, B. A. (2016) 'Costs of mandatory periodic audit partner rotation: Evidence from audit fees and audit timeliness', AUDITING: A Journal of Practice \& Theory, 36(1), pp. 129-149. doi: 10.2308/ajpt51515. https://doi.org/10.2308/ajpt-51515

Skinner, D. J., and Srinivasan, S. (2012) 'Audit quality and auditor reputation: Evidence from Japan', The Accounting Review, 87(5), pp. 1737-1765. https://doi.org/10.2308/accr-50198

Stanisic, N. et al. (2014) 'Auditor switching and qualified audit opinion: Evidence from Serbia', in The 2014 Proceedings of The first international Conference Sinteza, Belgrade, pp. 1-7. https://doi.org/10.15308/sinteza-2014-552-558

Stephanie, J. and Prabowo, T. J. W. (2017) 'Analisis faktor-faktor yang mempengaruhi auditor switching', Diponegoro Journal of Accounting, 6(3), pp. 38-49.

Svanberg, J. and Ohman, P. (2014) 'Lost revenues associated with going concerned modified opinions in the Swedish audit market', Journal of Applied Accounting Research, 15(2), pp. 197-214. doi: 10.1108/JAAR-11-20120077. https://doi.org/10.1108/JAAR-11-2012-0077

Udayani, N. K. S. and Badera, I. D. N. (2017) 'Kualitas audit sebagai pemoderasi pengaruh pergantian manajemen dan audit fee pada auditor switching', EJurnal Akuntansi, 20(3), pp. 1820-1847.

Wati, Y. (2020) 'Auditor switching: New evidence from Indonesia', The Indonesian Journal of Accounting Research, 23(1), pp. 87-126. doi: 10.33312/ijar.464. https://doi.org/10.33312/ijar.464

Whitworth, J. D., and Lambert, T. A. (2014) 'Office-level characteristics of the Big 4 and audit report timeliness', AUDITING: A Journal of Practice \& Theory, 33(3), pp. 129-152. doi: 10.2308/ajpt-50697. https://doi.org/10.2308/ajpt50697

Wijaya, E. and Rasmini, N. (2015) 'Pengaruh audit fee, opini going concern, financial distress, ukuran perusahaan, ukuran KAP pada pergantian auditor', E-Jurnal Akuntansi, 11(3), pp. 940-966.

Yudha, K. and Saputra, K. (2017) 'Pengaruh opini going concern, pergantian manajemen, kesulitan keuangan, dan reputasi auditor pada auditor switching', Jurnal Riset Akuntansi, 2(6), pp. 720-722. https://doi.org/10.7868/S0869565217060263 